\title{
Software Runtime Error
}

National Cancer Institute

\section{Source}

National Cancer Institute. Software Runtime Error. NCI Thesaurus. Code C92115.

The device software failed during operation as a result of a coding error. 